\title{
ОСОБЕННОСТИ УЧЁТА ЗАТРАТ И КАЛЬКУЛИРОВАНИЯ СЕБЕСТОИМОСТИ НА ПРЕДПРИЯТИЯХ ОБЩЕСТВЕННОГО ПИТАНИЯ
}

\author{
(C) 2021 Иванов Роман Анатольевич \\ кандидат экономических наук, доцент кафедры «Экономический анализ» \\ Кубанский государственный аграрный университет имени И. Т. Трубилина, Россия, Краснодар \\ Выполняя свою основную задачу, бухгалтерский учет предоставляет полную и достоверную ин- \\ формацию о деятельности организации и ее положении внутренним и внешним пользователям - \\ руководителям, учредителям, собственникам, инвесторам, кредиторам. В статье рассмотрены осо- \\ бенности учёта затрат и калькулирования себестоимости на предприятиях общественного питания.
}

Ключевые слова: учет, анализ, аудит, налогообложение, себестоимость, калькулирование себестоимости

Учет затрат на предприятиях общественного питания рассматривается как один из наиболее сложных ввиду того, что он сочетает в себе регулярный расчёт себестоимости производства большого количества готовых блюд, торговли и обслуживания, что подчеркивает необходимость в его детальном и подробном рассмотрении. У бухгалтерского учета на указанных предприятиях имеется своя специфика, хотя он и не регламентирован специальными отдельными нормативными актами бухгалтерского законодательства.

Для того, чтобы обеспечить возможность использования этих данных в целях правильного принятия управленческих решений и оценки эффективности предпринимательской деятельности, изначально следует наладить эффективное ведение бухгалтерского учета, осуществление контроля.

Как следует из Общероссийского классификатора видов экономической деятельности (ОКВЭД), предприятиями общественного питания не только производится и продается потребителю продукция питания, но также, что немаловажно, оказываются услуги общественного питания [3]. В соответствии с определениями, которые содержатся в Межгосударственном стандарте ГОСТ 31985-2013 «Услуги общественного питания. Термины и определения», услуга общественного питания представляет собой результат деятельности предприятия по удовлетворению потребностей потребителя в продукции общественного питания, а также в создании условий для реализации и потребления указанной продукции, в покупных товарах, в организации досуга и в иных дополнительных услугах.

Производство продукции выступает в качестве основного и первостепенного звена предприятия общественного питания (основное производство), в то время как остальные составляющие носят только вспомогательный характер.

Так, следует отметить, что организациями в рассматриваемой сфере деятельности чаще всего совмещаются производство и торговля. Соответственно, они могут находиться на разных режимах налогообложения. Как правило, и для ИП, и для ООО это специальные режимы УСН (упрощенная система налогообложения), не облагаемые НДС (налог на добавленную стоимость). Применяемый режим налогообложения значительным образом отражается на организации учета затрат, а также оказывает существенное влияние на налоговую нагрузку предприятия и размер налогооблагаемой базы.

Калькулирование себестоимости продукции общественного питания представляет собой весьма сложный и трудоемкий процесс, который требует наличия у бухгалтера-калькулятора особых навыков. Специфика указанной отрасли такова, что принцип учета затрат на предприятии общественного питания достаточно близок к заводскому производству со сложным технологическим процессом. Кроме того, существуют определенные специфические виды расходов и списаний.

К отраслевым особенностям рассматриваемых предприятий следует отнести регулярно проводимые инвентаризации и ревизии товарно-материальных ценностей. Это обусловлено рядом причин:

- реализация произведенной продукции происходит, как правило, в тот же день, преи- 
мущественно населению за наличный расчет, ее значительная часть является скоропортящейся, в связи с чем ей необходимо соблюдение условий хранения и оперативности списания при порче;

- большая часть продукции производится на основании промежуточных полуфабрикатов, которые могут быть многокомпонентными, что также необходимо оперативно учитывать.

Особенность определения себестоимости готового блюда состоит в том, что не все входящие в его состав ингредиенты могут быть напрямую включены в счет по цене закупки в соответствии с документами. Для того, чтобы правильного посчитать стоимость определенного компонента, прежде всего необходимо привести его к тому состоянию (очищено, сварено и пр.), в котором оно будет использовано. Технологическая карта является внутренним документом учета затрат, фиксирующим необходимые составляющие для производства блюда, их количество и стоимость.

Как уже указывалось ранее, товарооборот рассматриваемых предприятий состоит не только из продукции собственного производства, но и также оборота покупных товаров. В качестве особенности учета выступает необходимость одновременно учитывать и товарные позиции, и позиции, которые относятся к сырью. Такая двойственность использования ТМЦ обуславливает потребность в своевременном отслеживании пересортицы между счетами 41 и 10 в случае ее возникновения.

Разработка алгоритма учета затрат предприятия представляет собой важный элемент учетной политики, который оно определяет самостоятельно, используя при этом различные методики и отраслевые инструкции. Для бухгалтерского и налогового учета затрат важна их подтверждаемость, оправданность и обоснованность.

В процессе организации учета затрат на про- изводство внимание уделяется компьютернотехнической оснащенности учетного процесса.

К основным элементам системы управления себестоимостью продукции относятся: прогнозирование и планирование, нормирование затрат, учет и калькулирование, анализ и контроль за себестоимостью. Все перечисленные элементы функционируют в тесной взаимосвязи друг с другом. Эффективность производственного процесса характеризуется уровнем (удельным весом) понесенных затрат, а также размером себестоимости относительно конечной цены готовой продукции.

На рассматриваемых предприятиях для приготовления продукции заранее составляется план-меню, содержащий наименования и количество блюд, намеченных к приготовлению. На его основании в бухгалтерии устанавливаются розничные цены на блюда и составляется меню непосредственно для покупателей.

Калькуляция представляет собой элемент метода бухгалтерского учета, который предназначен для группировки, распределения затрат и исчисления себестоимости продукции (работ, услуг) по статьям затрат, объектам производства и учета.

Итак, решение о том, каким образом будет происходить осуществление калькулирования, каждое предприятие принимает самостоятельно, при учете того, что от структуры калькуляции непосредственно зависят методы и порядок учета затрат на производство, степень раскрытия информации о них, система плановых расчетов и характеристика получаемых при этом данных о себестоимости продукции (работ, услуг). Порядок бухгалтерского учета не закреплен нормативными актами на законодательном уровне, компании разрабатывают его самостоятельно, на базе отраслевых и методических рекомендаций, а также на основе практического опыта.

\section{Библиографический список}

1. Муканбетов Л.Б., Миннигалеева В.З. Проблемы бухгалтерского учета продажи готовой продукции // Направления совершенствования формирования учетно-аналитической информации в условиях решения современных проблем национальной экономики. Материалы Международной научно-практической конференции. Под редакцией Насретдинова И. Т. - Казань. - 2014. - С.100-101

2. Раицкий К. А. Экономика организации. - М.: Дашков и К, 2015. - С. 290.

3. Сокольская Е.И. Особенности калькулирования себестоимости в организациях общественного питания // Научно-методический электронный журнал «Концепт». - 2017. - Т. 31. - С. 186-190.

4. Основные правила ведения бухучета в общепите (нюансы). - Режим доступа: https://nalog-nalog.ru/ buhgalterskij_uchet/vedenie_buhgalterskogo_ucheta/osnovnye_pravila_vedeniya_buhucheta_v_obwepite_ nyuansy/ 